\title{
DECISION SUPPORT SYSTEM IN ASSESSMENT OF EMPLOYEE PERFORMANCE AT MNC GROUP USING SAW (SIMPLE ADDITIVE WEIGHTING) METHOD USING WHITE BOX TESTING
}

\author{
${ }^{[1]}$ Nur Roqim, ${ }^{[2]}$ Abdi Pandu Kusuma, ${ }^{[3]}$ Wahyu Dwi Puspitasari \\ ${ }_{1,2}$ Islamic University of Balitar; Jl. Majapahit No.04, Telp. (0342) 813145 \\ ${ }^{3}$ Jurusan Teknik Informatika, FTI Universitas Islam Balitar, Blitar \\ e-mail: ${ }^{1}$ nurrogim@gmail.com, ${ }^{2}$ abdipandukusuma@unisbablitar.ac.id, \\ 3wahyudwipuspitasari@ unisbablitar.ac.id
}

\begin{abstract}
:
MNC Group as a television media company, performs performance appraisal for each employee as a job evaluation material, which is carried out by the head of the division, one of which is the head of the technical division of 112 other employees. The process of evaluating employee performance at MNC Group is still done manually, which is using Microsoft Excel applications one by one which makes the length of the process. The employee's assessment and appraisal report does not display the ranking from the top to the bottom of all of the employees. Decision support system in evaluating employee performance in MNC Group using the SAW (Simple Additive Weighting) method with this white box test is made to assist the head of the division to expand employee appraisal capabilities. The employee performance appraisal process is carried out in a computerized, structured and systematic manner based on the assessment criteria previously determined by the MNC Group, namely the quantity of work, accuracy \& time management, quality of work and efficiency. The SAW (Simple Additive Weighting) method is a weighted addition method by looking for weighted sums of performance ratings on each alternative on all attributes. So that it can be obtained from every employee at MNC Group. Testing of system results that have been made is very necessary to know that the system is running well. Tests carried out are white box testing which is based on checking the details of the design, using the control structure of the program design procedurally to divide the test into several test cases. So that the value of the test results is known, namely 2 with the type of procedure is a simple procedure and the risk level is low risk.
\end{abstract}

Keywords: MNC Group, Employee Performance Assessment, Decision Support System, SAW Method, White Box Testing

\section{INTRODUCTION}

The quality of human resources is one of the factors needed to improve the quality of a company's performance productivity. Employee performance assessment must be carried out to determine the achievements and work results of each employee. Assessment carried out by the superior to each subordinate or employee shaded based on predetermined criteria (Waskito et al., 2016: 1).

MNC Group is one of the television media companies in Indonesia that has many employees with various positions, both in the center of 
Jakarta and in every region throughout Indonesia. MNC Group as a company also evaluates each employee as a work evaluation material, which is carried out by the head of the division, one of which is the head of technical division for 112 other employees. The process of evaluating employee performance at MNC Group is still done manually, which uses Microsoft Excel applications one by one which makes the duration of the process. The appraisal and report on the employee's assessment results do not show a score from the top to the bottom, of all the employees.

Therefore a decision support system was made in the assessment of employee performance in MNC Group using the SAW method (Simple Additive Weighting) with white box testing. Decision Support System (DSS) is a system to support decision makers to expand their capabilities, but not to replace their assessment (Kusumadewi and Purnomo, 2010: 1). The process of evaluating employee performance is carried out in a computerized, structured and systematic manner based on assessment criteria predetermined by MNC Group, namely the quantity of work, accuracy \& time management, quality of work and efficiency. SAW Method (Simple Additive Weighting) is a weighted sum method by looking for weighted sums of performance ratings on each alternative on all attributes. So that can be obtained rengking from each employee at the MNC Group.

Testing of the results of the system that has been made is very necessary to know that the system is running well. The test is done by testing the white box. White box testing is a test that is based on checking the detailed design, using a control structure from a procedural design program to divide the test into several test cases (Liana, 2015: 6). So that it can be seen how the application is running well and valid.

Based on the description above, a decision support system was made in the assessment of employee performance in MNC Group using the SAW method (Simple Additive Weighting) with white box testing. In 
JOSAR, Vol. 1 No. 1 March, 2018; p-ISSN: 2502-8251; e-ISSN: 2503-1155

Copyrights@ Balitar Islamic University, Blitar-Indonesia

https://ejournal.unisbablitar.ac.id/index.php/josar

order to make it easier for the head of the technical division as a user to properly assess each employee.

\section{Research Methods}

\section{A. Time And Place of Research}

The object of this research was carried out in MNC Group, with one of the transmission offices from MNC Group located in Batu City - Malang. With the focus of research on employee performance appraisal systems, where the assessment process was previously carried out using Microsoft Office.

\section{B. Data Collection Method}

\section{Observation}

The initial steps taken in an effort to collect data and information about the problems of the research that was raised were observations on the MNC Group. Observations on employee performance appraisal at MNC Group include the employee performance appraisal process, assessment criteria data and the weighting values used in the current employee performance appraisal process.

\section{Literature Review}

This data collection technique is done by looking for theories from reading sources to become the basis of research activities. Reading resources used are from books, journals and guidelines or standard form companies in the assessment of employee performance.

\section{System Design}

System design is the process of developing a new system based on the results of a system requirements analysis recommendation. The design contains various descriptions of the data, processes and interfaces of the proposed new system. 
JOSAR, Vol. 1 No. 1 March, 2018; p-ISSN: 2502-8251; e-ISSN: 2503-1155

Copyrights@ Balitar Islamic University, Blitar-Indonesia

https://ejournal.unisbablitar.ac.id/index.php/josar

1. DFD

a. DFD LEVEL 0

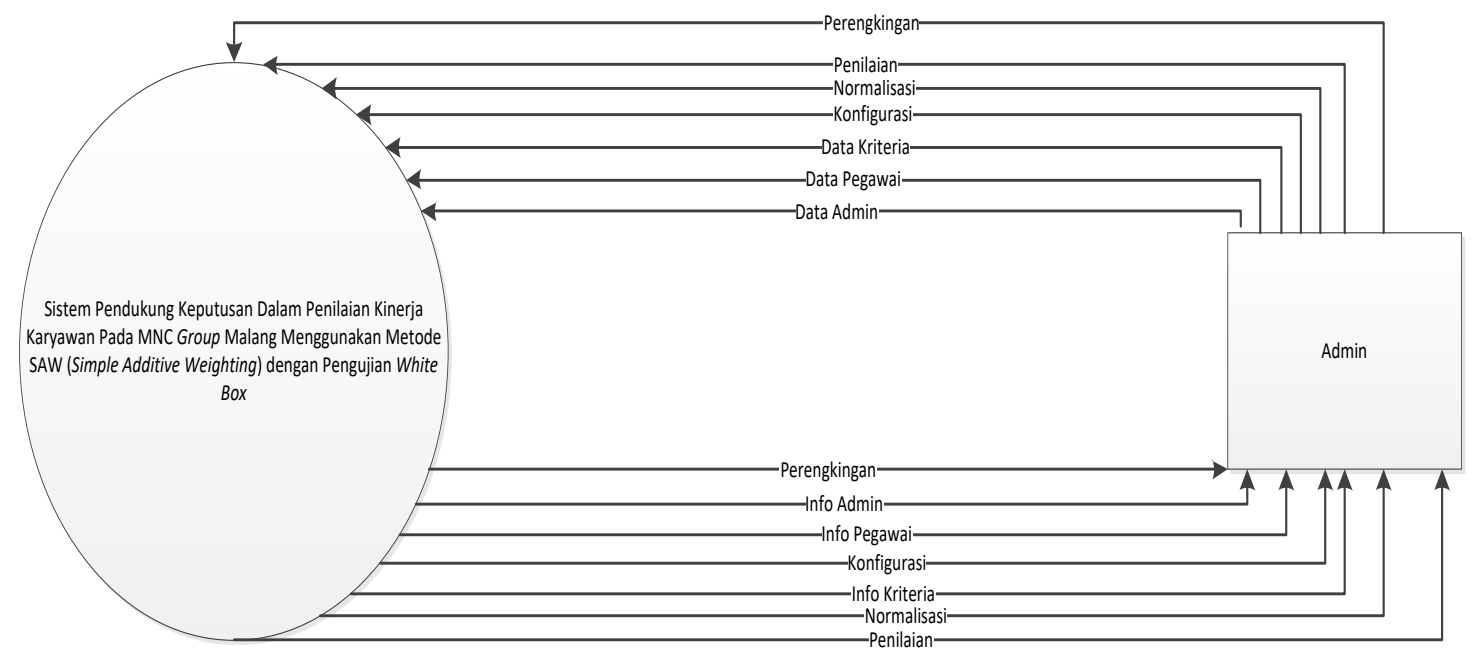

Figure 1 DFD level 0

In Figure 1 shows the DFD level 0 of the decision support system in the assessment of employee performance in MNC Group using the SAW method (Simple Additive Weighting) with white box testing. There is one user associated with the system, namely admin with all the access rights contained in the system. Admin can process data input into the system, evaluate performance according to the process flow and get output system results. 
JOSAR, Vol. 1 No. 1 March, 2018; p-ISSN: 2502-8251; e-ISSN: 2503-1155

Copyrights@ Balitar Islamic University, Blitar-Indonesia

https://ejournal.unisbablitar.ac.id/index.php/josar

b. DFD LEVEL 1

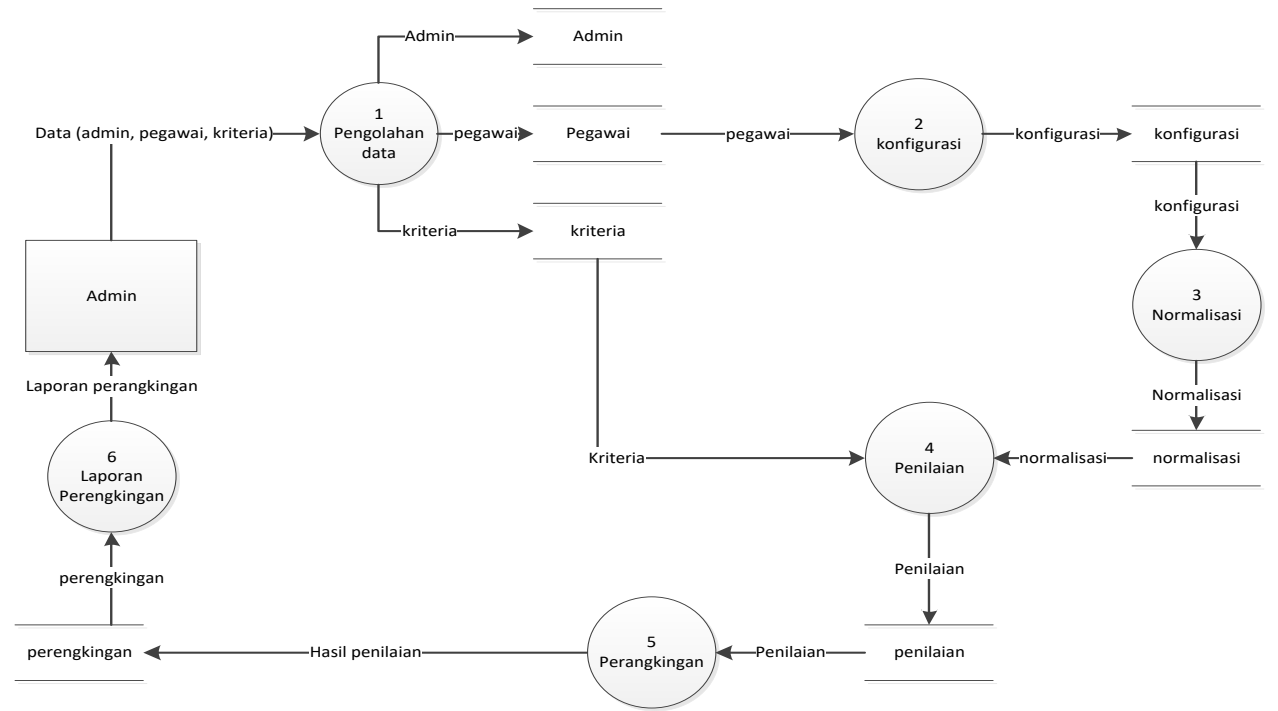

Figure 2 DFD Level 1

In Figure 2 shows the DFD Level 1 of the decision support system in the assessment of employee performance in MNC Group using the SAW method (Simple Additive Weighting) with white box testing where the admin can do 7 processes in the system, namely data processing, configuration, normalization, valuation, cracking and cracking reports. 
JOSAR, Vol. 1 No. 1 March, 2018; p-ISSN: 2502-8251; e-ISSN: 2503-1155

Copyrights@ Balitar Islamic University, Blitar-Indonesia

https://ejournal.unisbablitar.ac.id/index.php/josar

\section{FLOWCHART}

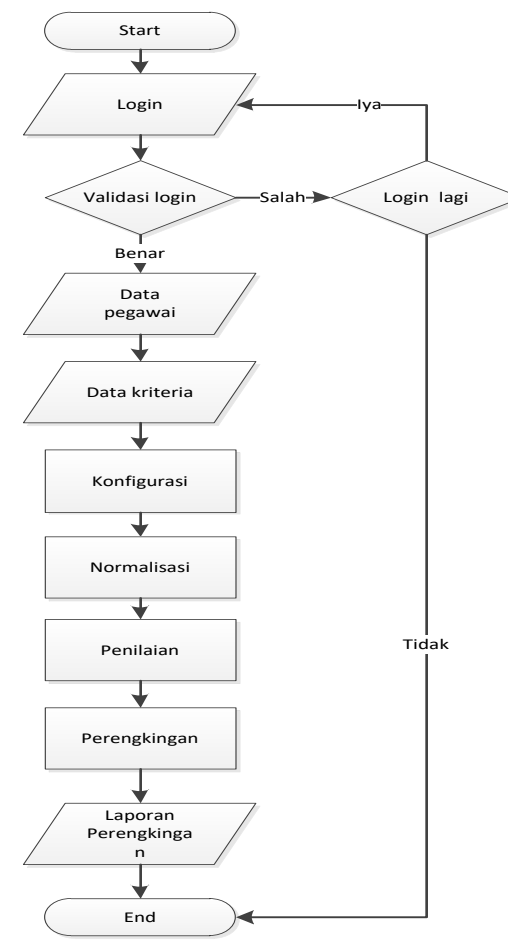

Figure 3 Flowchart

In Figure 3 shows the flowchart or process flow of the decision support system in the assessment of employee performance in the MNC Group. Where the system starts from the login process to enter the system. After that the admin input the required data starting from employee data, criteria and configuration criteria data for each employee. To further conduct the assessment process which includes the normalization of configuration data, the valuation is weighted from the normalization and crawl matrix. Until the results of cracking are obtained from employee performance in accordance with the data that has been entered. 
JOSAR, Vol. 1 No. 1 March, 2018; p-ISSN: 2502-8251; e-ISSN: 2503-1155

Copyrights@ Balitar Islamic University, Blitar-Indonesia

https://ejournal.unisbablitar.ac.id/index.php/josar

3. ERD

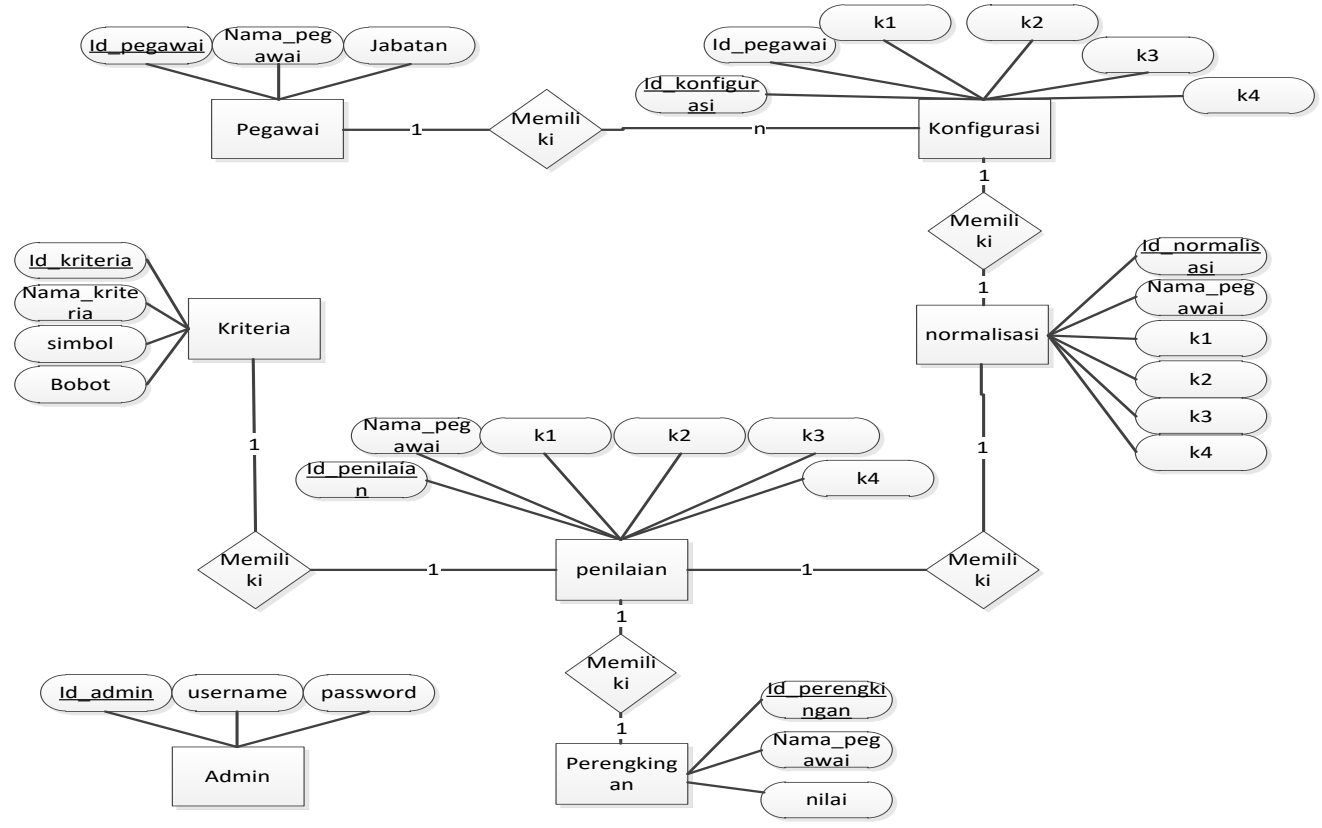

Figure 4 ERD

In Figure 4 shows the ERD (Entity Relationship Diagram) of tables that are related to each other or related in the system. The table includes employee tables, configuration, criteria, normalization, valuation, cracking and admin tables.

\section{IPO TABLE}

In decision support systems in the assessment of employee performance in MNC Group has input, process and output in accordance with the system requirements needed. So the system can run well. As shown in table 1 below. 
JOSAR, Vol. 1 No. 1 March, 2018; p-ISSN: 2502-8251; e-ISSN: 2503-1155

Copyrights@ Balitar Islamic University, Blitar-Indonesia

https://ejournal.unisbablitar.ac.id/index.php/josar

TABLE 1 TABLE IPO

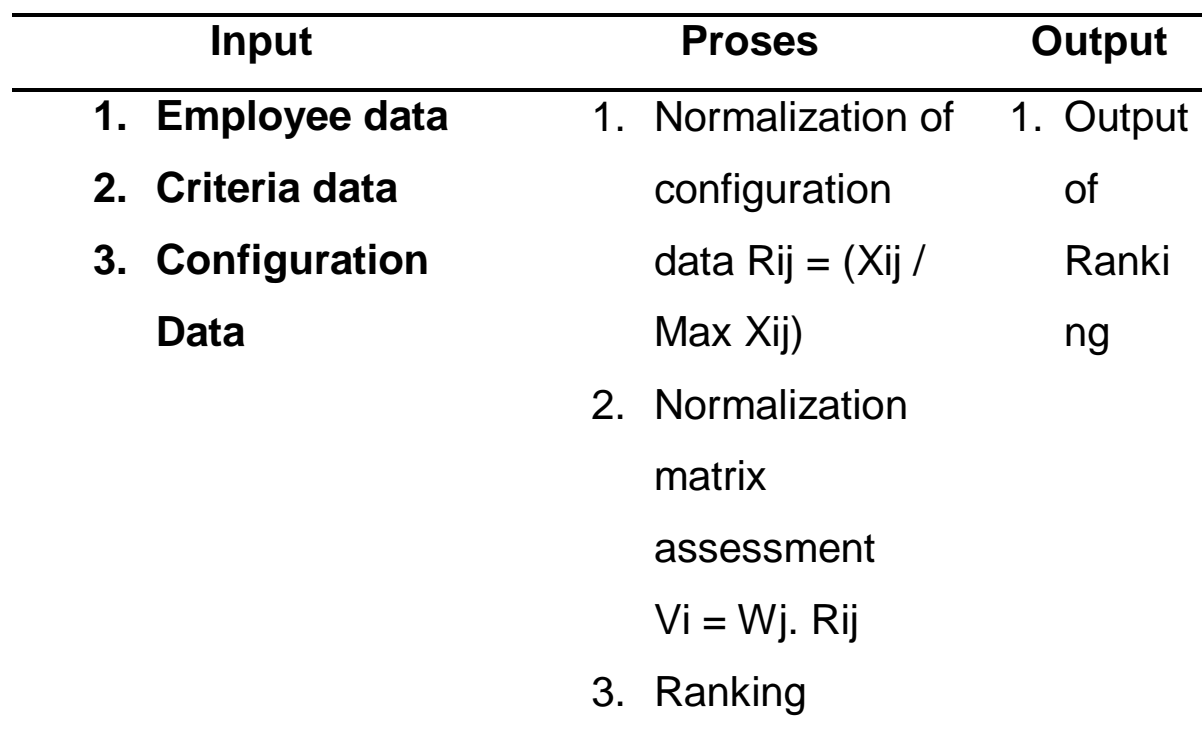

\section{RESULT AND DISCUSSION}

This stage is done after the design stage is complete. After it is implemented, it is carried out on the system and we see the shortcomings of this application for further system development.

\section{A. Program Interface}

\section{Konfiguration Page}

The configuration page is a page that functions to manage configuration data between employee data and predetermined criteria data. That is by entering each employee data and providing criteria values in each existing criteria column as shown in figure 5 below. 
JOSAR, Vol. 1 No. 1 March, 2018; p-ISSN: 2502-8251; e-ISSN: 2503-1155

Copyrights@ Balitar Islamic University, Blitar-Indonesia

https://ejournal.unisbablitar.ac.id/index.php/josar

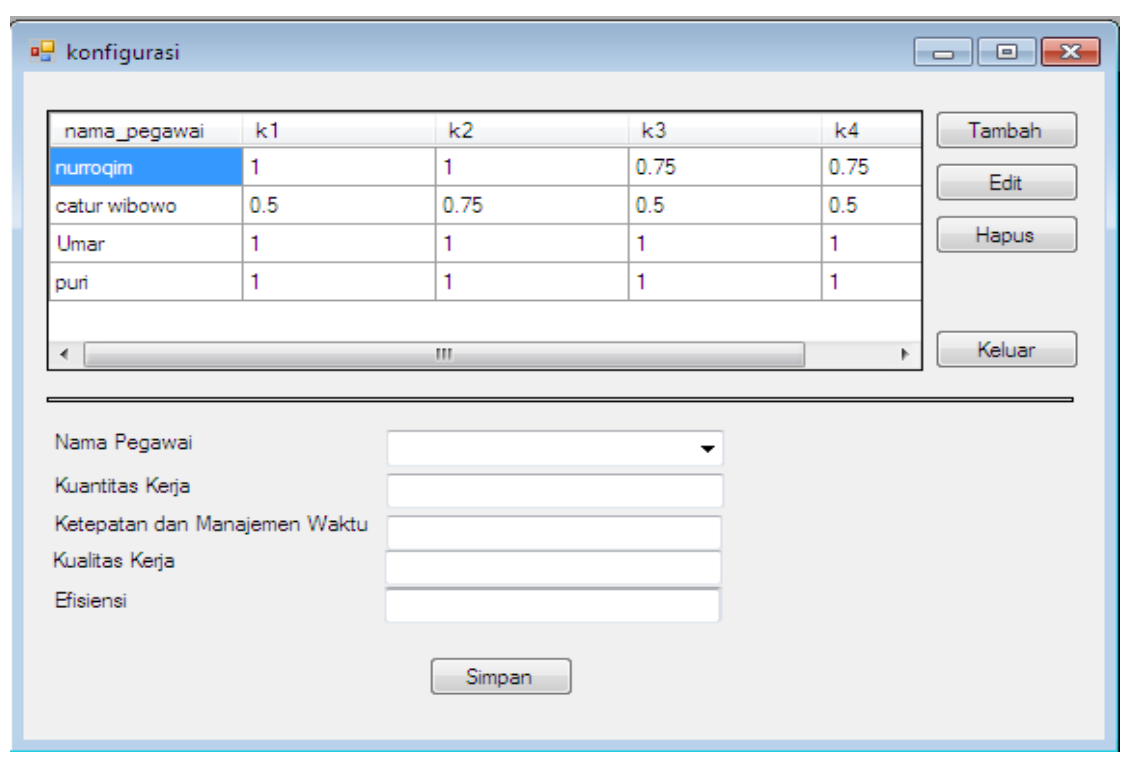

Figure 5 Konfiguration Page

\section{Normalization Page}

The normalization page is a page that functions to carry out the process of data normalization, which is the data resulting from the previous configuration process. So that new data is obtained, namely normalization data as shown in the following figure.

\begin{tabular}{|c|c|c|c|c|c|}
\hline 吅 normalisasi & & & & & \begin{tabular}{|l|l|}
0 & 0 \\
\end{tabular} \\
\hline nama_pegawai & k1 & k2 & $k 3$ & $k 4$ & Proses Normalisasi \\
\hline nunroqim & 1 & 1 & 0.75 & 0.75 & \\
\hline catur wibowo & 0.5 & 0.75 & 0.5 & 0.5 & \\
\hline Umar & 1 & 1 & 1 & 1 & \\
\hline puri & 1 & 1 & 1 & 1 & \\
\hline 1 & & & & 7 & Keluar \\
\hline
\end{tabular}

Figure 6 Normalization Page

\section{Rating Page}

The rating page is a page that serves to conduct an employee performance appraisal process, based on normalization data that has 
JOSAR, Vol. 1 No. 1 March, 2018; p-ISSN: 2502-8251; e-ISSN: 2503-1155

Copyrights@ Balitar Islamic University, Blitar-Indonesia

https://ejournal.unisbablitar.ac.id/index.php/josar

been done before. So that the final value of the assessment process has been obtained. And the final results are displayed sequentially according to the highest to lowest score as shown in Figure 7 below.

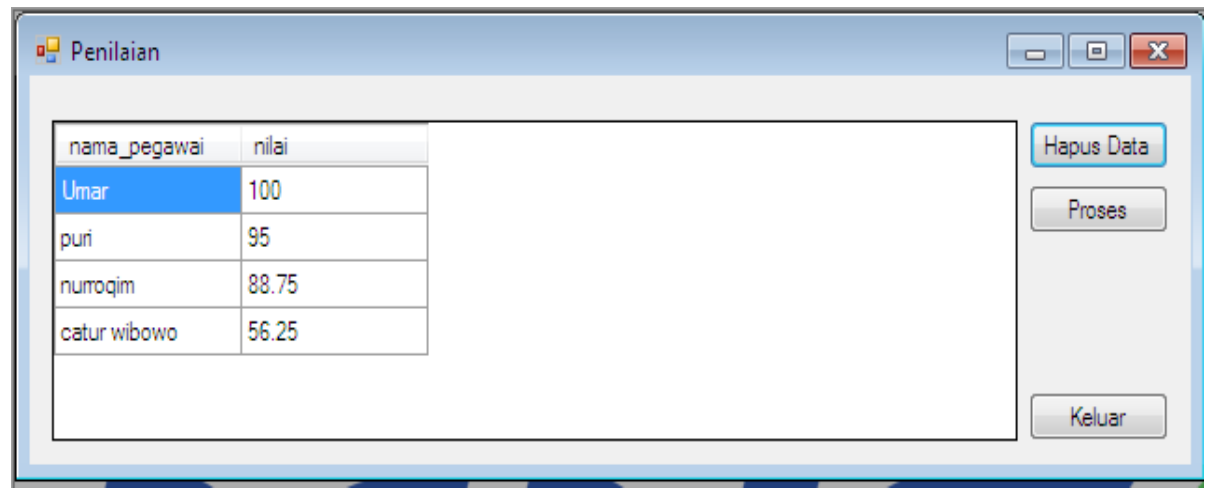

Figure 7 Rating Page

\section{B. White Box Testing}

\section{Tasting on the Rating Page}

In testing on the normalization page there are several steps as follows:

\section{a) Mapping the Source Code of Rating Page}

At this stage the researcher maps the parts of the rating page source code into the table.

\section{b) Create Flow Graph From the Mapping of Source Code}

After the researcher maps the parts of the assessment source code to the table, the researcher draws a picture of the flow of the system or flow graph as shown in the following figure: 
JOSAR, Vol. 1 No. 1 March, 2018; p-ISSN: 2502-8251; e-ISSN: 2503-1155

Copyrights@ Balitar Islamic University, Blitar-Indonesia

https://ejournal.unisbablitar.ac.id/index.php/josar

Figure 8 Flow Graph Rating Page

\section{c) Cyclomatic Complexity}

From the flow graph in Figure 8 it is known that there are 10 nodes and 9 edges. A node is a sequence of process symbols. While edge is an arrow that describes the flow of the control according to the flow diagram. Then it can be used to calculate the cyclomatic complexity as follows:

$$
\begin{aligned}
\mathrm{V}(\mathrm{G}) \quad & =\mathrm{E}-\mathrm{N}+2 \\
& =9-10+2 \\
& =1
\end{aligned}
$$

Keterangan :

$$
\begin{array}{ll}
\mathrm{V}(\mathrm{G}) & =\text { Cyclomatic complexity } \\
\mathrm{E} & =\text { Number of Edge } \\
\mathrm{N} & =\text { Number of Node }
\end{array}
$$

From the results of the calculation, above it is known that the value of the cyclomatic complexity is 2 . With the type of procedure is a simple procedure and the risk level is low risk. 
JOSAR, Vol. 1 No. 1 March, 2018; p-ISSN: 2502-8251; e-ISSN: 2503-1155

Copyrights@ Balitar Islamic University, Blitar-Indonesia

https://ejournal.unisbablitar.ac.id/index.php/josar

d) Independent Path

From the results of the calculation of cyclomatic complexity, there are 1 path as follows:

Path 1 : 1-2-3-4-5-6-7-8-9-10

e) Graph Matrix

From 1 path that has been determined in the independent path can be tested with the graph matrix as follows:

TABLE 2 TABLE OF Graph MATRIX

\begin{tabular}{|c|c|c|c|c|c|c|c|c|c|c|c|}
\hline & 1 & 2 & 3 & 4 & 5 & 6 & 7 & 8 & 9 & 10 & $N(E)-1$ \\
\hline 1 & & 1 & & & & & & & & & $1-1=0$ \\
\hline 2 & & & 1 & & & & & & & & $1-1=0$ \\
\hline 3 & & & & 1 & & & & & & & $1-1=0$ \\
\hline 4 & & & & & 1 & & & & & & $1-1=0$ \\
\hline 5 & & & & & & 1 & & & & & $1-1=0$ \\
\hline 6 & & & & & & & 1 & & & & $1-1=0$ \\
\hline 7 & & & & & & & & 1 & & & $1-1=0$ \\
\hline 8 & & & & & & & & & 1 & & $1-1=0$ \\
\hline 9 & & & & & & & & & & 1 & $1-1=0$ \\
\hline \multicolumn{12}{|c|}{10} \\
\hline & & & & & & & & & otal & +1 & $0+1=$ \\
\hline & & & & & & & & & & & 1 \\
\hline
\end{tabular}

Based on table 2 above, it is known that the results of calculations between nodes and edges using graph matrix are obtained results 1. Which indicates that the value of cyclomatic complexity and independent path is appropriate.

\section{ConCLUSION}

Based on the research conducted in the discussion of the previous article, some conclusions can be taken as follows: 
a. The design of a decision support system in assessing employee performance in MNC Group has several stages. Starting from making DFD, ERD, Flowcharts and IPO tables. As well as designing the interface of each system page that will be created.

b. Decision support system in evaluating employee performance in MNC Group is implemented using the SAW (Simple Additive Weighting) method. With the process, it includes inputting employee data, determining criteria and weighting criteria, configuring employee data against the criteria used, normalizing values and evaluating. So that the final score of each MNC Group employee is achieved, from the highest to the lowest.

c. In the white box testing that has been done on the login, configuration, normalization and rating pages there are several stages. These stages are starting from source code mapping, creating flow graphs, calculating cyclometic complexity, determining the independent path, making graph matrix, performing test scenarios on each page to be tested. Where the results of the cyclometic complexity and matrix graph of each page tested have the same value, namely 2 . With the type of procedure is a simple procedure and the risk level is a low risk of several pages that have been tested.

\section{REFERENCES}

Anwar, Syaiful. 2016. Sistem Pendukung Keputusan Pemberian Pinjaman Kepada Nasabah Menggunakan Metode Simple Additive Weighting (SAW). Skripsi. Tidak dipublikasikan. Blitar : Universitas Islam Balitar.

Frieyadie. 2016. Penerapan Metode Simple Additive Weighting (SAW) Dalam Sistem Pendukung Keputusan Promosi Kenaikan Jabatan. Skripsi. Tidak dipublikasikan. Jakarta : AMIK BSI Jakarta.

Gumelar, Agum. 2017. Sistem Pendukung Keputusan Pemilihan Handphone Dengan Metode Simple Additive Weighting (SAW) Berbasis WEB.. Skripsi. Tidak dipublikasikan. Surakarta : Universitas Muhammadiyah Surakarta. 
JOSAR, Vol. 1 No. 1 March, 2018; p-ISSN: 2502-8251; e-ISSN: 2503-1155

Copyrights@ Balitar Islamic University, Blitar-Indonesia

https://ejournal.unisbablitar.ac.id/index.php/josar

Liana, Linda. 2015. Pengujian Perangkat Lunak (Software Testing). Skripsi. Tidak dipublikasikan. Jakarta : Universitas Mercu Buana.

Nugroho, Aryo dan Community, SmitDev. 2008. Belajar Sendiri Mengimplementasikan SQL Server 2008. Jakarta : PT. Elex Media Komputindo

Santiary, Putri Alit Widyastuti. 2012. Sistem Pendukung Keputusan Cerdas Dalam Penentuan Penerima Beasiswa. Jurnal Logic. 12(2), 87-91

Situmorang, Harold. 2015. Sistem Pendukung Keputusan Pemilihan Calon Peserta Olimpiade Sains Tingkat Kabupaten Langkat Pada Madrasah Aliyah Negeri (MAN) 2 Tanjung Pura Dengan Menggunakan Metode Simple Additive Weighting (SAW). Skripsi. Tidak dipublikasikan. Sumatra Utara : Universitas Sumatra Utara.

Sukamto, Rosa A, dan Shalahudin, M. 2011. Modul Pembelajaran Rekayasa Perangkat Lunak (Terstruktur dan Berorientasi Objek). Bandung : Modula

Waskito, Rizaldi Rahman, Bagus Setya dan Daryanto. 2016. Sistem Pendukung Keputusan Penilaian Kinerja Karyawan Dengan Menggunakan Metode Simple Additive Weighting Pada PTPN XII Perkebunan Malangsari. Skripsi. Tidak dipublikasikan. Jember : Universitas Muhammadiyah Jember.

Westriningsih. 2010. Paling Dicari Visual Basic 2010 Source Code. Yogyakarta : Penerbit Andi

Yuswanto dan Subari. 2010. BOOM..! Visual Basic .NET 2010 Meledak. Jakarta : Cerdas Pustaka Publisher 